\title{
Twenty first century development in the Hungarian Defence Forces: The KC-390 tactical military transport aircraft
}

\section{HISTORICAL BACKGROUND}

Recognizing the need for the air transport of passengers and cargo for military purposes, aircraft were already systematized for this task in Hungary between the two world wars.

Although the aim of the article is not to describe all the transport aircraft used in the history of the Hungarian Defence Forces ${ }^{2}$, it is necessary to cover the type of gear that precedes the military airlift capability that was due for renewal and fulfils its tasks within the framework of the Zrínyi Program. One of those assets is the An-26 military transport aircraft, not only because she has served for

Figure 1. Embraer's KC-390 Millennium aircraft (Source: Embraer S.A.)

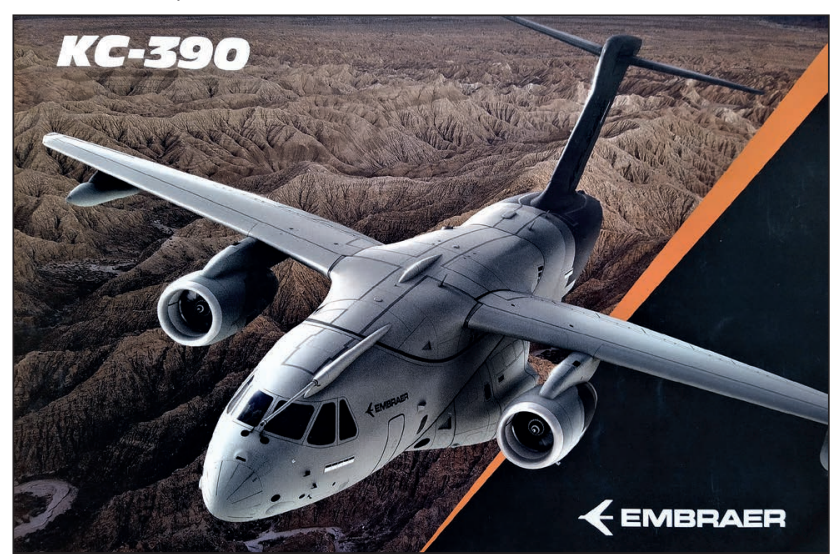

ÖSSZEFOGLALÁS: A tanulmány rövid történeti képet vázol a Magyar Honvédség egyes korszakaiban a légi szállító képességet megtestesitő egyes repülőgépekről, valamint légi és földi üzemeltetést biztosító állományról. A Zrínyi Honvédelmi és Haderófejlesztési Program keretein belül kialakítandó katonai szállító repülő képesség ismertetésével az olvasó rálátást kap a kiteljesedő komplex légiszállitási képességre és mindazon megvalósítandó feladatra, amelyek a szövetségesi, nemzetközi és hazai szerepvállalások során a jövőben keletkeznek.

A cikk részletesen ismerteti a közeljövőben beszerzésre kerülő Embraer KC-390 Millennium típusú új katonai szállitó repülőgépet.

KULCSSZAVAK: KC-390, katonai szállitó repülőgép, Magyar Honvédség, Zrínyi Honvédelmi és Haderőfejlesztési Program, NATO nearly half a hundred years, but also because we can understand some of the present capability requirements from the mission set of this aircraft.

\section{An-26t ${ }^{3}$ Tactical Military Transport Aircraft}

The domestic history of the An-26 aircraft (Figure 2) began in 1973, when a decision was made to retire the legacy Li-2 transport aircraft.

Figure 2. The archive image includes the An-26 aircraft and its crew (form right Lt. Col. József Torma Dep. Com. of the Squadron - Pilot in Command, Maj. Sándor Kiss Squadron Observer, Maj. László Vaik Co-pilot, SSgt. András Balogh Airborne Systems Specialist, WO. József Tóth Airborne Radio Operator, unknown) in preparation for the April 4 parade, Szolnok, March 1975 (Source: unknown)



ABSTRACT: The paper gives a short historical overview of the types of aircraft representing airlift capabilities in certain periods of the life of the Hungarian Defence Forces and pays tribute to air and ground operations personnel. Describing the military transport aircraft capabilities to be developed within the framework of the Zrínyi Defence and Military Development Program ${ }^{1}$, the reader will gain insight into the ever evolving he reader will gain insight into the ever evolving nature of complex airlift capabilities and the tasks resulting from participation in Alliance, international and domestic missions.

The article provides a detailed description of the new, soon to be acquired military transport aircraft Embraer KC-390 Millennium.

KEY WORDS: KC-390, military transport aircraft, Hungarian Defence Forces, Zrínyi Defence and Military Development Program, NATO

\footnotetext{
Lieutenant Colonel senior aviation officer of the HDF Command Force Planning Directorate Capability Development Programs Branch. University of Public Service Faculty of Military Science and Officer Training Doctoral School of Military Sciences, doctoral student. ORCID: 0000-0002-7735-2173
} 
The basic ideas for the novelty of the type development itself - the new design of the rear cargo door or ramp, its loading functions and the ability to be pulled under the trunk - already existed in 1964, yet the prototype was only completed by the end of 1968 .

In 1974, the Hungarian Air Force received 6 pieces (registered with tail number 202; 203; 204; 208; 209; 210) of the large-scale series production, which started in 1970, and another 4 pieces with tail number 405; 406; 407; 603.

Of particular interest is the fact that the type was already viewed and recognized by the Western trade press in 1969. It can be said that at that time we got modern, newly developed aircraft according to the standards of the age.

The typical mission set of the An-26, which had been constantly developing over the years, was as follows:

- performing air transport tasks related to the international role of the HDF (especially support of operations in the Baltics and the Balkans - limited applicability ${ }^{4}$;

- provision of medical air evacuation tasks (AIREVAC 5 );

- participation in the tasks of the OPEN SKIES agreement ${ }^{6}$ with Hungary;

- support for joint force operations (theatre air transport, airborne missions such as dropping paratroopers or cargo);

- performing other domestic and international air transportation tasks (including government VIP, dignitary transportation);

On May 11, 2020, the defence leadership made a decision on the type, according to which neither an extension of the operating time nor a heavy maintenance could be planned.

Withdrawal of the type from the system had to be carried out for airplanes $110^{7}, 405,406,407$, and 603, still service at the time.

On June 23, 2020, tail number 406 aircraft reached the limit of its time between overhauls, thus, with its last flight, concluded the domestic career of the type by ending its active service.

The An-26 aircraft nicknamed "Screaming Mouse", of which 11 flew in Hungary during its 46 years of service (202, $203,204,208,209,210,405,406,407,603,110$ ), accumulated about 83,000 flown hours and completed 31 million $\mathrm{km}^{8}$.
The retraining of the personnel flying An-26s to flying new types of aircraft and planning for new task is in progress, as a result of which only 3 of the approximately 26 crew members have been transferred to other aviation professions.

The decommissioning of the type has temporarily removed the following capabilities:

- Aerial photography for cartographic purposes, tasks covered by the OPEN SKIES agreement;

- Air transport of persons and cargo on the battlefield;

- Airborne operations both personnel and cargo;

- Transport of weapons, explosive or dangerous goods by air;

- MEDEVAC capability9;

- Possibility of retraining air crews for Multi Engine Operations $\left(\mathrm{ME}^{10}\right)$.

\section{DEVELOPMENT OF THE MILITARY TRANSPORT CAPABILITIES OF the Hungarian Defence Forces}

At the strategic level, the idea of the replacement of the existing An-26 fleet arose as early as 1997, as the 4 aircraft available used the remaining operating time based on the operating time indicators at that time. In the first round, at the invitation of CASA, an expert-level consultation was held on a CN-235 aircraft with a Sevillebased company in Spain. Subsequently, in 1998, at the invitation of the Lockheed Martin Aeronautical System in Great Britain, the RAF Lyneham Air Base hosted a site surway where the C-130K Hercules aircraft was in the crosshairs. Based on the travel reports and expert analyses of the negotiations, the military leadership of the time assessed that it would be expedient to return to the issue of type change after Hungary's forthcoming accession to NATO. Of course, there was another nonnegligible aspect, which happened to be that the program could not be launched in the actual medium-term planning period (until 2003) due to extremely limited budgetary resources. Another significant problem of the procurement was the lack of a complete infrastructural condition of the airport receiving the new type, as well as the considerable cost impact of implementation.

Figure 3. The last official flight of the An-26 aircraft (tail number 406) of the HDF (Source: Nóra Letanóczki)

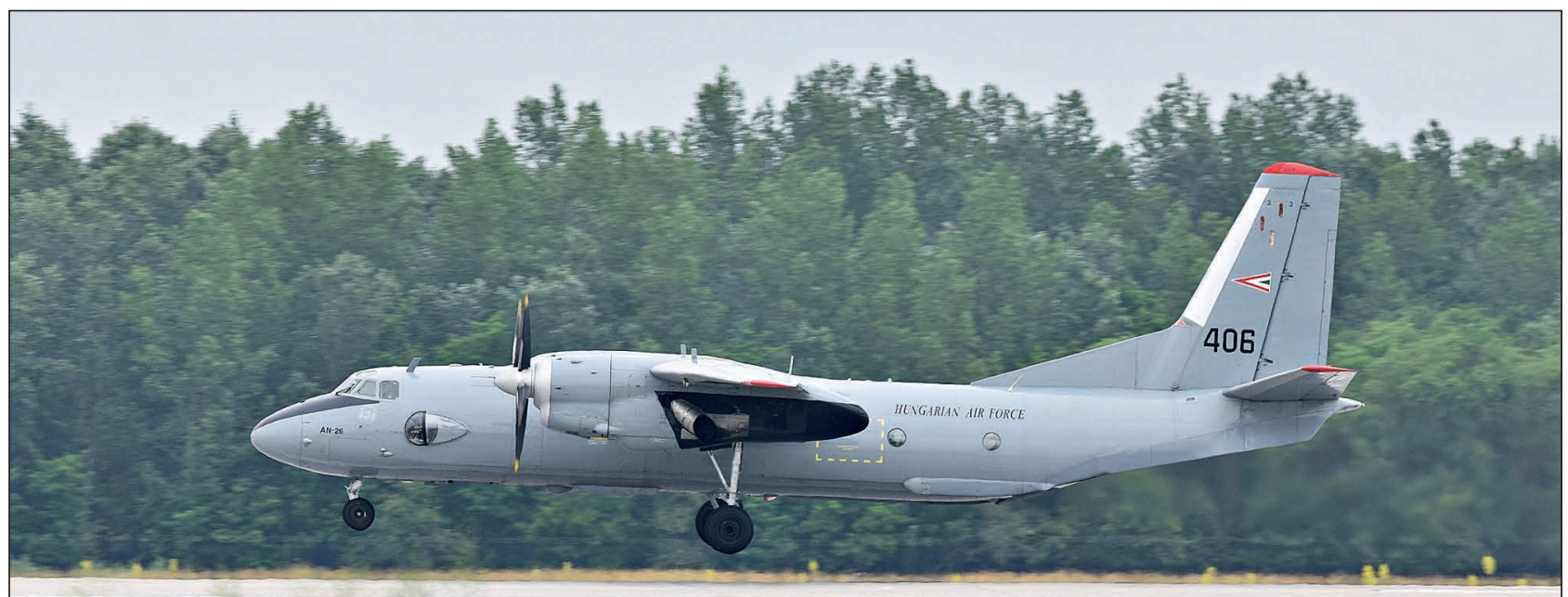


Table 1. Airbus A319-112 and Dassault Falcon $7 X$ transport aircraft main technical data (Source: edit by author)

\begin{tabular}{|l|c|c|}
\hline \multicolumn{1}{|c|}{ Parameters } & Airbus A319-112 & Dassault Falcon 7X \\
\hline Max Payload & $126 \mathrm{pax} / 70 \mathrm{tons}^{*}$ & $14 \mathrm{pax} / 2,5$ tons \\
\hline Max Cruising Speed & $830 \mathrm{~km} / \mathrm{h} / 0.78 \mathrm{M}$ & $850 \mathrm{~km} / \mathrm{h} / 0.85 \mathrm{M}$ \\
\hline Service Ceiling & $11.700 \mathrm{~m} \mathrm{(FL} \mathrm{390)}$ & $12.900 \mathrm{~m}(\mathrm{FL} \mathrm{430)}$ \\
\hline Ferry Range & $11.100 \mathrm{~km}$ & $\mathrm{~N} / \mathrm{A}$ \\
\hline Ferry Range with max payload & $6.945 \mathrm{~km}$ & $10.200 \mathrm{~km}$ \\
\hline Crew & $1 \mathrm{PIC} ; 1 \mathrm{FO} ; 1 \mathrm{FM} ; 1 \mathrm{LM} ; 3-4 \mathrm{CA}^{\star *}$ & $1 \mathrm{PIC} ; 1 \mathrm{FO} ; 1 \mathrm{FE} ; 1 \mathrm{CA}$ \\
\hline
\end{tabular}

* AIREVAC, MEDEVAC depends on its configuration

** PIC - Pilot in Command; FO - First Officer; FM - Flight Manager; LM - Load Master; CA - Crew Attendant; FE - Flight Engineer

\section{RENEWAL OF AIR TRANSPORT CAPABILITIES}

With the accession to NATO, a new era had begun for both Hungary and the HDF. The military air transport capacity available at the time was only sufficient to perform a fraction of the projected tasks. In addition, the An-26 aircraft, which represented the technological standards of the 1960s, posed increasing difficulties in the design and execution of tasks, both technically and in terms of applicability.

Within the framework of the Zrínyi Program, there was a real opportunity to develop military transport aircraft capabilities in line with Hungary's air transport tasks and level of ambition, thus reducing or eliminating the risk of exposure due to the lack of capabilities and the impact of high rental costs. Such a strategically important capabilities contribute to the full performance of the tasks of the HDF arising from its basic mission, independent from external factors, ensuring the preparation and training of soldiers for operational tasks, transport and replenishment of soldiers and equipment and the possibility of active participation in humanitarian missions.

\section{PURCHASE PHASE 1}

In addition to the 2 Dassault Falcon $7 X$ long range, multipurpose liaison and transport aircraft (Figure 4), the 2 Airbus A319-112 troop transport aircraft (Figure 5) are suitable for the fast, safe and efficient transport of HDF personnel and their personal equipment, but in the case of an air evacuation task it is also available to Hungarian citizens. Due to its modular interior design, it can also be suitable for performing air medical evacuation tasks. The performance data of A319 and F7X and the names of the new on-board positions are summarized in Table 1.

\section{PURCHASE PHASE 2}

A team of experts preparing the procurement examined the capabilities of a tactical military transport aircraft in line with NATO expectations and conducted negotiations accordingly.

- Tactical Air Transport (AT) Requirements [1]:

Tactical (Intra-theatre) AT provides airlift within a specific theatre or $\mathrm{JOA}^{11}$. It differs from Strategic AT in its greater exposure to the enemy threat and therefore in its higher theatre entry standards; in localised command and control; in the coordination and synchronicity with

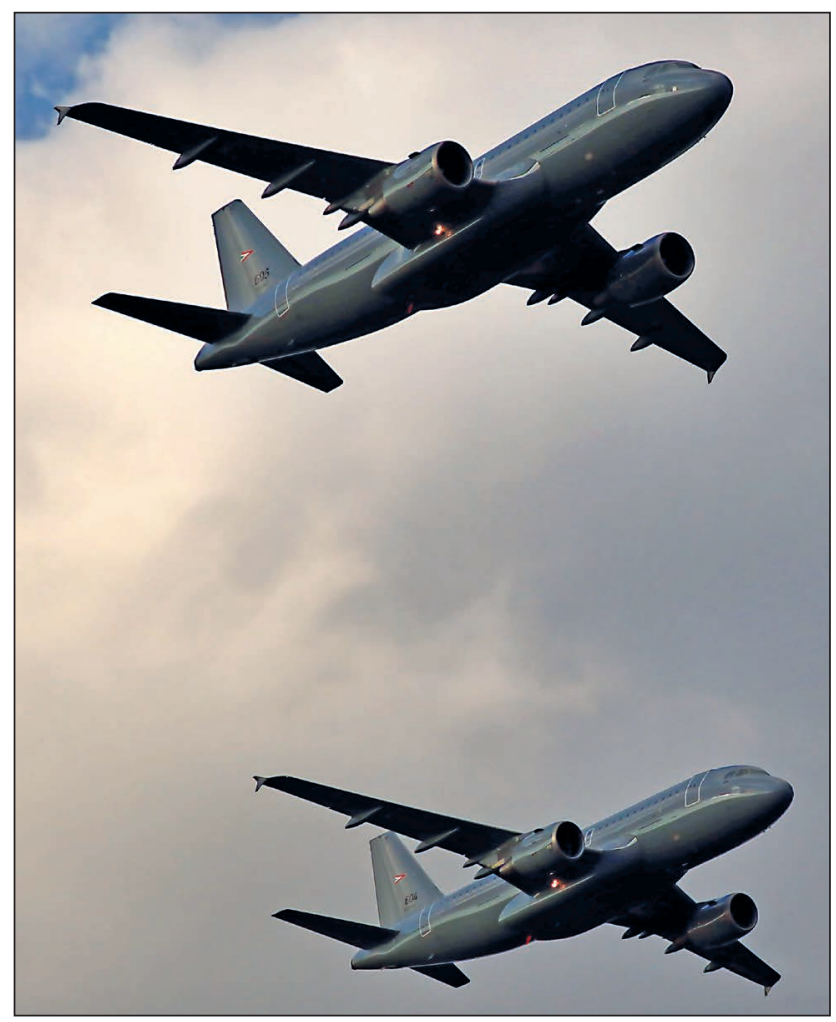

Figure 4. Airbus A319-112 Troop transport aircraft (Source: Nóra Letanóczki)

Figure 5. Dassault Falcon F7X Light, multi-purpose liaison and transport aircraft (Source: Nóra Letanóczki)

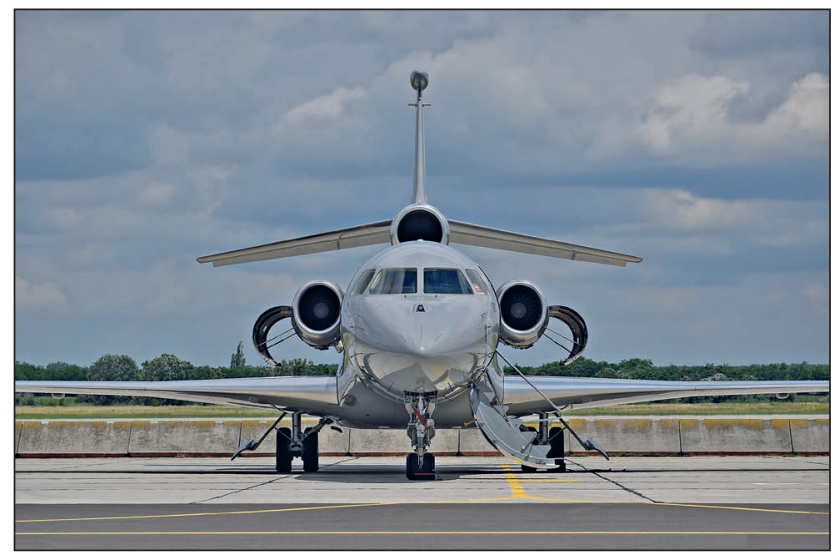


the operational battle rhythm and scheme of manoeuvre; and in its capability to operate from performancelimiting, austere landing strips. For these reasons Tactical AT platforms are restricted in terms of outsized cargo capacity and range in comparison to Strategic AT platforms.

- Required Force Elements:

The effectiveness of Alliance operations (in terms of deployment, mobility and sustainment) hinges upon the availability of intra-theatre airlift, especially in the case of expeditionary operations and/or when operating in areas with poor transport infrastructure. ISAF operations in Afghanistan were constrained by a lack of intra-theatre airlift; however, this is attributed more to a lack of Rotary-Wing lift rather than Fixed-Wing AT. The statistics, however, show that there are sufficient numbers amongst the Alliance members to fulfil this AT requirement. Where the failure lies is the lack of standardisation in training and platform capabilities, and the consistent reluctance of nations to offer these capabilities to the Coalition. Quite often those nations who lack a Strategic AT capability mitigate this shortfall by utilising tactical assets instead.

- Tactical AT Platform Characteristics ${ }^{12}$ :

The Tactical AT include the following criteria [2]:

- Capable of Aerial Fire Fighting;

- Capable of Air Ambulance Operations;

- Capable of tactical transportation/Airlift of cargo up to six tonnes or up to 20 fully combat equipped soldiers;

- Capable of performing reconnaissance (including: Maritime Patrol; Weather \& Aerial Sampling);

- Capable of conducting Combat Search and Rescue (CSAR) operations in no-to-low threat environments only, primarily to provide aerial refuelling to rescue helicopters;

- Capable of automatic response to external electronic interrogation by military and civilian ground and airborne interrogators;

- Capable of bi-directional networked air-air and airsurface communications;

- Capable of secure, Electronic Warfare resistant voice and data communication;

- Capable of EW/Electronic Combat;

- Capable of ice-strip operations (modified wheel-ski landing gear);

- Capable of day/night and all weather operation, including low-level flights;

- Capable of airborne refuelling of Fixed- and Rotary Wing aircraft;

- Capable of ground refuelling (both Fixed-Wing and Rotary-Wing \& fuel caches whilst engines are still running with props feathered);

- Capable of being refuelled in-flight;

- Capable of autonomous or mutual initiation of selfprotection measures;

- Capable of passively detecting approaching surface air missiles;

- Capable of passively detecting, analysing and identifying hostile radar emissions from airborne and ground threats in dense EM environments;

- Capable of airdrop operations of cargo and supplies;

- Capable of airborne troop deployment.

The points taken in bold from the listed capability elements also appeared as a basic requirement during the Hungarian procurement procedure.

In light of the above, preparations began in 2018 for the development of a new tactical military transport aircraft with intra-theatre airlift capabilities, which make it possible to perform tasks in a high-risk area of operations.

The main tasks of the type are the autonomous provision of support to the defence forces by covering air transport needs, joint operations (battlefield air transport, airborne operations both personnel and cargo, etc.), as well as the performance of domestic and international air transport tasks (Table 2).

Table 2. KC-390 transport aircraft main performance data (Source: edit by author)

\begin{tabular}{|l|l|}
\hline Parameters & KC-390 \\
\hline Max payload & $\begin{array}{l}23 \text { tons or } \\
80 \text { equipped soldiers or } \\
66 \text { paratroopers }\end{array}$ \\
\hline Max cruising speed & $\begin{array}{l}556 \mathrm{~km} / \mathrm{h} \text { at sea level } \\
0.78 \mathrm{M} \text { at } 9.000 \mathrm{~m} \text { (FL300) }\end{array}$ \\
\hline Service Ceiling & $10.500 \mathrm{~m}$ (FL 350) \\
\hline Ferry Range & $7.100 \mathrm{~km}$ (with AAR tanks) \\
\hline $\begin{array}{l}\text { Range with operating } \\
\text { payload }\end{array}$ & $2.000 \mathrm{~km}(19,5$ tons) \\
\hline Crew & $\begin{array}{l}1 \mathrm{PIC} ; 1 \mathrm{FO} ; 1 \mathrm{FE} ; 1 \mathrm{FM} ; 1 \\
\mathrm{LM} ; 1 \mathrm{AAR} \text { OP* }\end{array}$ \\
\hline
\end{tabular}

* PIC - Pilot in Command; FO - First Officer; FE - Flight Engineer; FM - Flight Manager; LM - Load Master; AAR OP - Air-to-air Refuelling Operator.

The subject of the procurement is basically the acquisition of 2 aircraft of the same capabilities and equipment which are suitable for full NATO interoperability, both for peacetime and military operations.

Negotiations have taken place with the Brazilian aerospace company Embraer S.A. Founded in 1969 as a state-owned company, the Brazilian aviation company manufactures commercial, military and business jets as well as agricultural aircraft. The company was completely separated from government management in 1997 and then listed on the stock exchange in 2000. Today, it is the 3rd largest aviation company in the world.

As a result of a series of negotiations between the two parties, a contract for the supply of 2 new Embraer KC-390 Millennium tactical military transport aircraft and the equipment, training, related services and logistical support required for their operation and maintenance was signed on 17 November 2020 [3]. According to the terms of the agreement, the planes will arrive in the year 2024.

It is interesting to note that Embraer contacted the Ministry of Defence with this type already in 2014, but under the conditions of that time capability development was not possible, so the current acquisition of KC-390 provides a framework suitable for this path-finding process.

The KC-390 aircraft to be purchased will have the following capabilities:

1. Battlefield transport of forces: An airplane with a middle row of seats (Figure 6) can be used to deploy a maximum of 80 soldiers or 66 paratroopers with full equipment.

2. Battlefield cargo/equipment transport: The aircraft is capable of carrying a maximum of 23 tons of cargo in unit loads, or depending on their size, a combat vehicle and a helicopter (Figure 7). Among the cargo stowage 


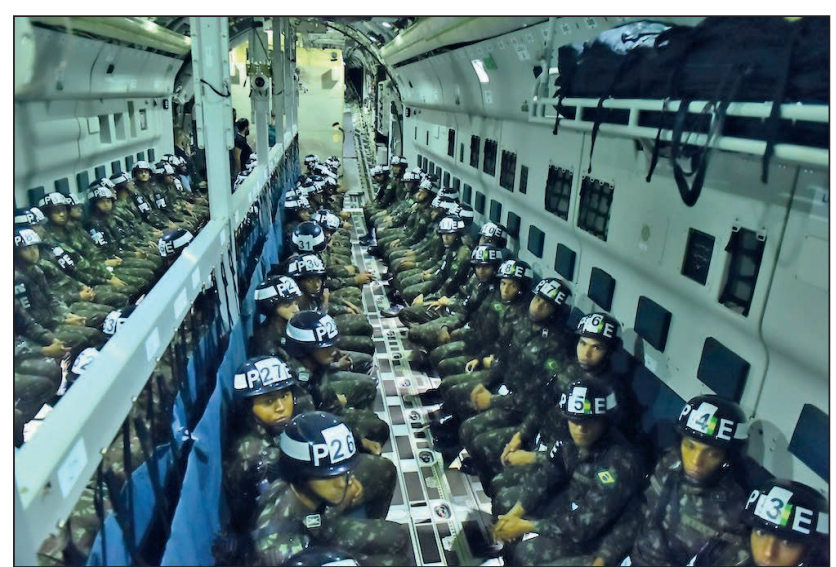

Figure 6. Troop transport using a middle row of seats (Source: Embraer S.A.)

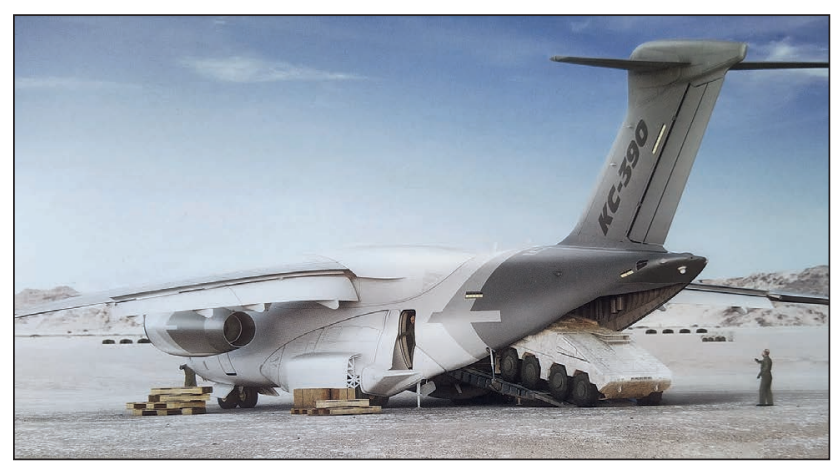

Figure 7. In-theatre air transport (Source: Embraer S.A.)

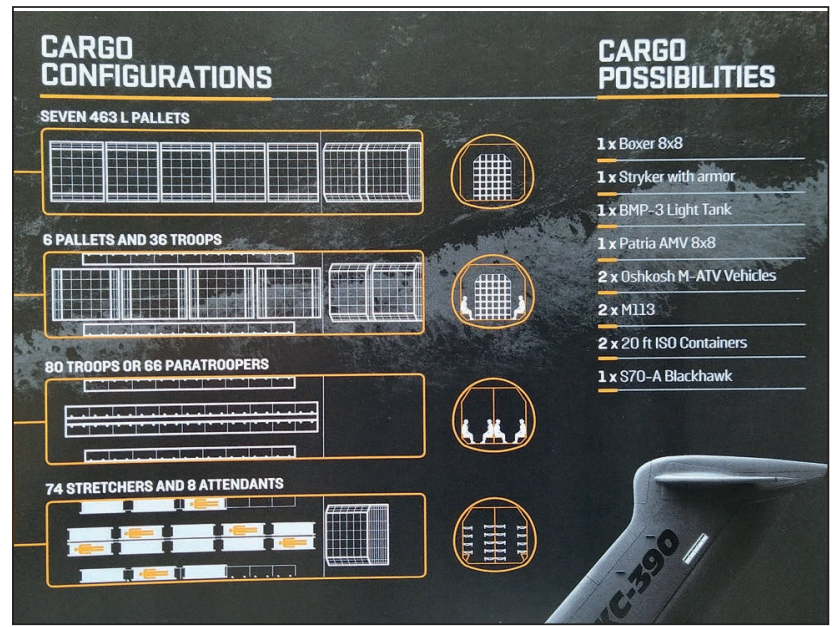

Figure 8. Loading variants (Source: Embraer S.A.)
Table 4. Size and weight data of military equipment typically transported on a KC-390 transport aircraft (Source: edit by author)

\begin{tabular}{|l|c|c|}
\hline Type of vehicle & $\begin{array}{c}\text { Weight } \\
\text { (tons) }\end{array}$ & $\begin{array}{c}\text { Dimensions } \\
(\mathbf{L} \times \mathbf{W} \times \mathbf{H})\end{array}$ \\
\hline Oshkosh M-ATV & 12.5 & $6.27 \times 2.49 \times 2.7$ \\
\hline M113 & 12.3 & $4.9 \times 2.7 \times 2.5$ \\
\hline
\end{tabular}

variants (Figure 8), in addition to the load required to perform a given task or to provide logistical support, a limited number of people can also be placed on board. With this capability, a significant part of the domestic and international air transport demands can be covered, including the logistic support of high-priority Air Policing tasks.

Task-specific military equipment, unit load, equipment, personnel loading and layout variants [4]:

- 1 vehicle (Table 3.)

-2 vehicles (Table 4.)

$-2 \times 20$ feet ISO Containers;

$-7 \times 436$ L Pallets;

$-6 \times 436$ L Pallets and 36 Troops;

- 80 Troops or 66 Paratroopers;

- 74 Stretchers and 8 Attendants for AIREVAC Missions;

- 8 Intensive Care Unit (ICU) possibility of installation.

3. Both aircraft have a Passive Self-Protection System (fix and removable armour against 7,62 $\mathrm{mm}$ ammo) and an Active Self-Protection System (Chaff \& Flare, DIRCM ${ }^{13}$ Figure 9);

4. The aircraft is capable of using the worst semic-prepared runway and operate on reduced or damaged soft unpaved airfields (Figure 10);

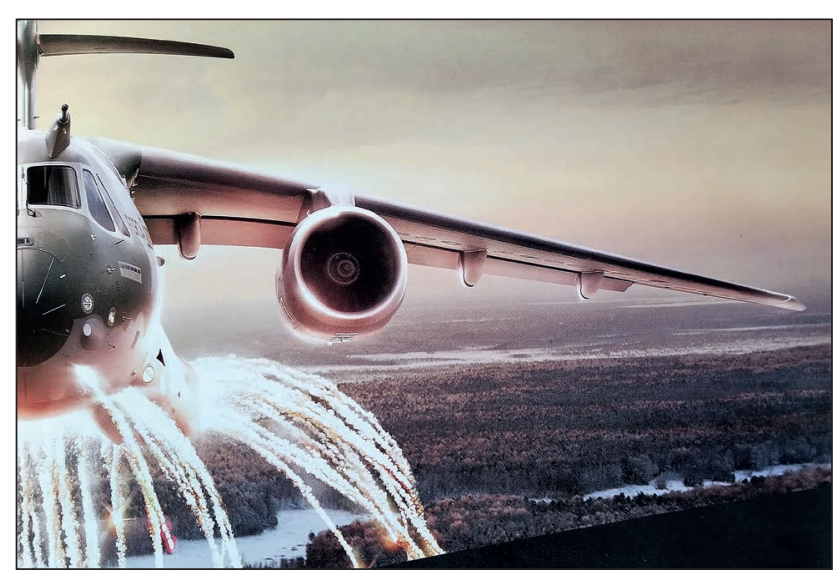

Figure 9. KC-390 aircraft using Active Self-Protection System (Source: Embraer S.A.)

Table 3. Size and weight data of military equipment typically transported on a KC-390 transport aircraft (Source: edit by author)

\begin{tabular}{|l|c|c|}
\hline \multicolumn{1}{|c|}{ Type of vehicle } & Weight (tons) & Dimensions $(\mathbf{L} \times \mathbf{W} \times \mathbf{H})$ \\
\hline Boxer 8×8 & 24 & $7.93 \times 2.99 \times 2.37$ \\
\hline Stryker with armour & M1126: 18.51 (with additional armour 21) & $6.95 \times 2.72 \times 2.64$ \\
\hline BMP-3 light tank & 18.7 & $7.14 \times 3.2 \times 2.4$ \\
\hline Patria AMV 8×8 & $16-27$ & $7.7 \times 2.8 \times 2.3$ \\
\hline S70-A Blackhawk & 5.35 & ca.14.5 $\times$ ca.3.2 $\times$ ca.3.4 \\
\hline
\end{tabular}




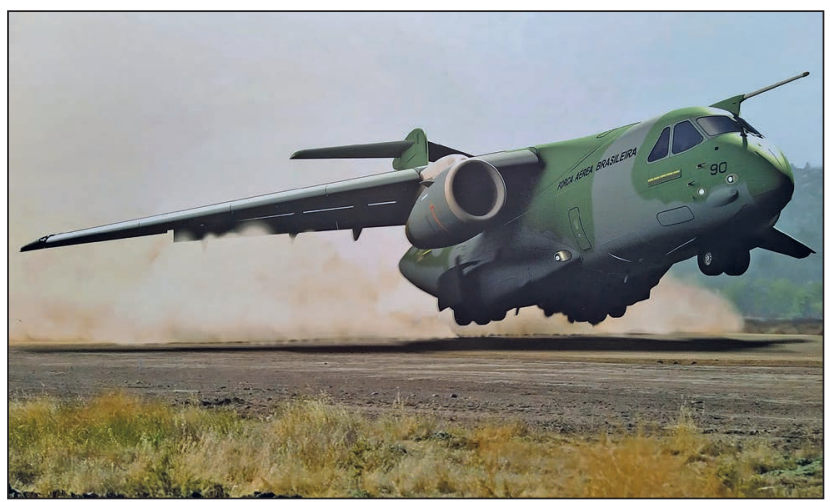

Figure 10. KC-390 during take-off from a semi-prepared runway (Source: Embraer S.A.)

5. Human and cargo air drop (Figure 11): Can be performed at low altitudes and high altitudes (HAHO, $\mathrm{HALO}^{14}$ ), supported by an on-board oxygen system. A cord is installed in the cargo area to perform a static line jump. In the case of one aircraft, manual and programmed/timed dropping of loads is also possible $\left(\mathrm{CCDP}^{15}\right)$;

6. In the case of one aircraft the AIREVAC capability will be developed with 74 stretchers, while the MEDEVAC ${ }^{17}$ capability will be developed with a pre-installation to serve 4 intensive care units (ICU ${ }^{18}$ or PTU ${ }^{19}$ acquisition appears as a later capability development, Figure 12). The ICU is the same as the one used on the A319.

7. Air-to-air Refuelling- and Receiver Aircraft Capability (Figure 13):

One of the two aircraft to be procured is equipped with a complete $A A^{20}$ system. The AAR capability will provide Gripen with the ability to maintain proficiency and is expected to be a sought-after capability for the region as well. The operating range of a receiver aircraft during a coalition operation is estended significantly, especially when used at full payload. The range can also be increased with the extra fuel provided by the AAR tanks, but this reduces the payload capacity.

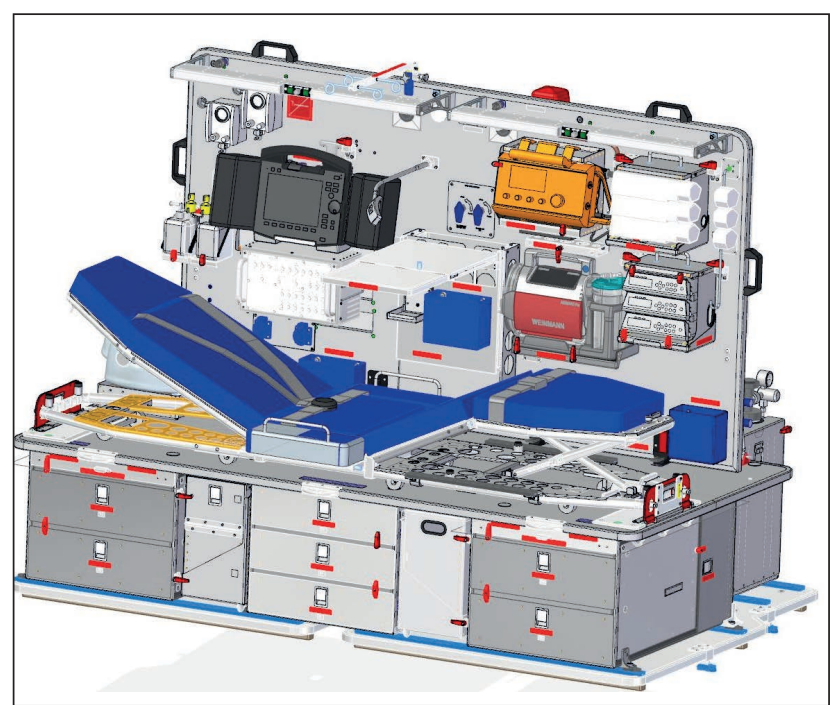

Figure 12. Patient Transport Unit (Source: MH Egészségügyi Központ)

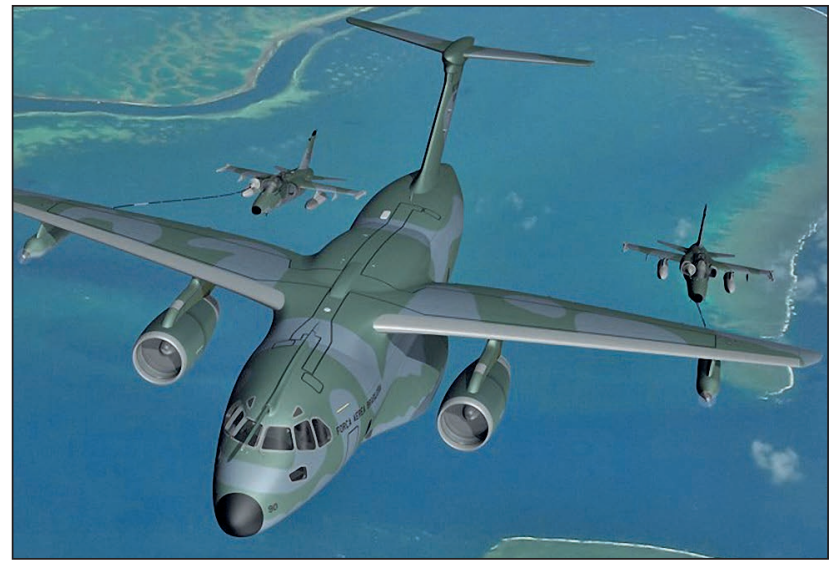

Figure 13. A KC-390 during Air-to-air Refuelling Operation (Source: Embraer S.A.)

Figure 11. KC-390 during Human and Cargo Air Drop (Source: Embraer S.A.)

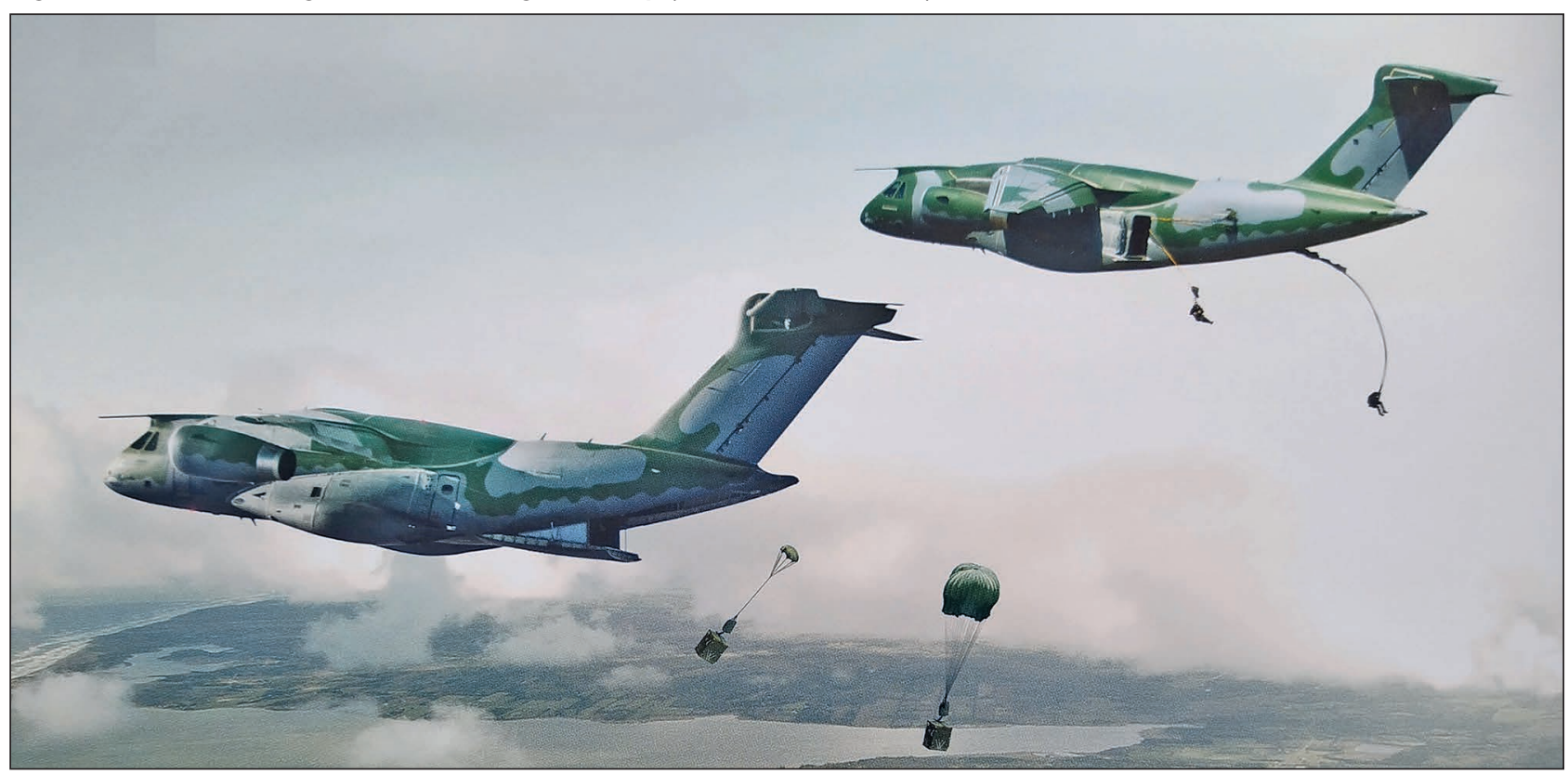


Table 5. KC-390 Summary of Transport Aircraft Capabilities (Source: edit by author)

\begin{tabular}{|l|c|}
\hline Summary of the capability elements & \\
\hline $\begin{array}{l}\text { Active Self-Protection System (Chaff \& Flare, } \\
\text { DIRCM) } \\
\text { Passive Self-Protection System (fix and } \\
\text { removable armour against 7,62 mm ammo) }\end{array}$ & $\checkmark$ \\
\hline $\begin{array}{l}\text { Refuelled as Receiver Aircraft and Air-to air } \\
\text { Refuelling Capability }\end{array}$ & $\checkmark$ \\
\hline $\begin{array}{l}\text { NVIS } 21 \text { Interior, Exterior and Cockpit System } \\
\text { Lights Compatible }\end{array}$ & $\checkmark$ \\
\hline $\begin{array}{l}\text { AIREVAC (74 Stretchers and 8 Attendants) }+ \\
\text { MEDEVAC (4 Intensive Unit - ICU/PTU) }\end{array}$ & $\checkmark$ \\
\hline $\begin{array}{l}\text { Human Air Drop (cord for jumping, HALO and } \\
\text { Oxygen System) }\end{array}$ & $\checkmark$ \\
\hline Middle Row of Seats & $\checkmark$ \\
\hline Continuous Computed Drop Point (CCDP) & $\checkmark$ \\
\hline Worst Semi-Prepared Runway Use & $\checkmark$ \\
\hline $\begin{array}{l}\text { Secure Mode Military Communications and } \\
\text { Navigation Equipment }\end{array}$ & $\checkmark$ \\
\hline Ground Maintenance and Support Systems & $\checkmark$ \\
\hline Computer Based Trainer (CBT) & $\checkmark$ \\
\hline Simulator (FFS 22 ), Tactical Simulation System & $\times^{23}$ \\
\hline Combat Search and Rescue & $\times^{24}$ \\
\hline Aerial Photography and Aerial Sensing & $\times$ \\
\hline
\end{tabular}

\section{SUMMARY}

A historical parallel can be drawn between the introduction of the An-26 and KC-390 tactical military transport aircraft in Hungary, as in the case of both aircraft it can be said that domestic procurement took place in a relatively short time after its development and international launch. Moreover, both types possess features and modern abilities and capabilities that fit the tasks of the HDF. This also means that Hungary, as one of the first to apply the new type, is

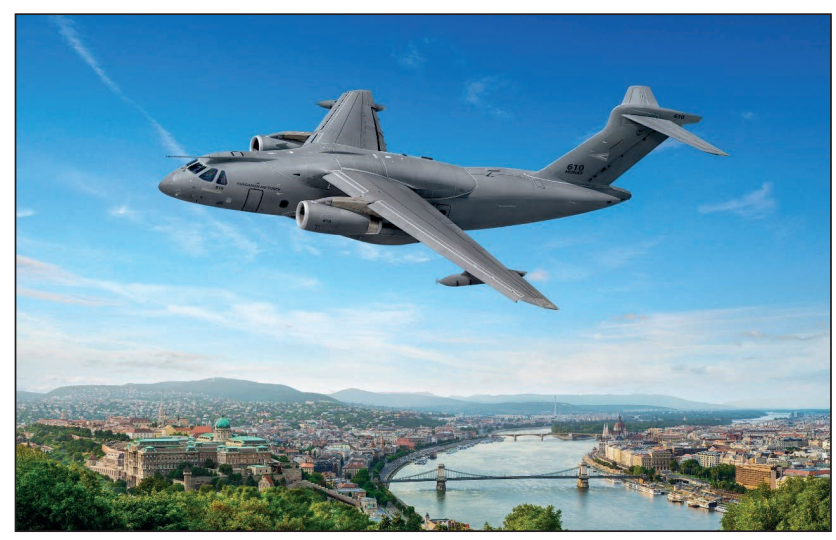

Figure 14. A fictitious photograph taken by Embraer in honour of the agreement (Source: Embraer S.A.)

likely to make a major contribution to the "fine-tuning" of the aircraft and to the modernization of individual subcapabilities, either as a partner or as a first-time user.

The KC-390 aircraft (Figure 16), with its personnel trained, prepared and qualified, will be able to perform the tasks described in this article in accordance with NATO requirements after reaching full operational capability.

The acquisition of this particular aircraft restores a number of capability goals that were temporarily lost with the retiring of the An-26 aircraft and provides new ones that we have never had before. As a result, Hungary will have some of the most modern intra-theatre transport capabilities in the Central European region.

\section{BIBLIOGRAPHY}

[1] Joint Air Power Competence Centre, „NATO Air Transport Capability", August 2011.;

[2] STANAG 3700 (Ed. 7) Allied Joint Doctrine for Air and Space Operations - AJP-3.3 (A);

[3] Draveczki-Ury Ádám. „KC-390-es hadszíntéri szállító repülőgépeket vásárol a Magyar Honvédség” 2020. november 17. https://honvedelem.hu/hirek/kc-390es-hadszinteri-szallito-repulogepeket-vasarol-amagyar-honvedseg.html (Letöltés: 2021.3.10.);

[4] STANAG 7166 (Ed. 1) Air Forces Logistic Doctrine and Procedures - ALP-4.3 (ALP-13).

\section{NOTES}

1 Hereinafter: Zrínyi Program.

2 Hereinafter: HDF.

3 Transzportnij (in Russian) - transport version (not usually marked, because it is also a transport aircraft according to its basic purpose)

4 The An-26 medium transport aircraft is primarily suitable for tactical (short-range) transport.

5 AIREVAC - Aero-Medical Evacuation.

6 More about the agreement: http://aviatika.rkk.hu/openskies.html.

7 In 2004, with the 4 An-26s kept in the system, it was becoming increasingly difficult to meet the transport demands of foreign missions, therefore the aircraft with page 110 was purchased from Ukraine.

8 Estimation of maintenance personnel. Exact data is not available because all documentation for the airplane first purchased and then withdrawn was previously destroyed.

9 In the case of the Airbus A319, with the on-board integration of a PTU (Patient Transport Unit), the capability is temporarily available with limitations.
10 Multiengine Course.

11 Joint Operations Area.

12 According to the NATO Bi-SC Agreed Capability Statements (dated 16 April 2008)

13 Directional Infrared Countermeasure.

14 High Altitude High Operating; High Altitude Low Operating.

15 Continuous Computed Drop Point.

16 Disaster Evacuation Module.

17 Medical Evacuation with ICU.

18 Intensive Care Unit.

19 Patient Transport Unit.

20 Air-to-air refuelling.

21 Night Vision Imaging System.

22 Full Flight Simulator.

23 Capability building is not currently planned; it is recommended to implement it in the users group cooperation.

24 The capability does not appear on the Hungarian version. 